\title{
Mirko Vranić
}

\author{
Laboratorija za bioarheologiju, Odeljenje za arheologiju, \\ Filozofski fakultet, Univerzitet u Beogradu \\ mirkov4@gmail.com
}

\section{Uticaj srednjovekovnog rudarstva na životnu sredinu centralnog Balkana}

Apstrakt: Sa razvojem rudarstva od sredine XIII veka dolazi do pojave naselja u blizini mesta eksploatacije i prerade rude. Platoi na pošumljenim planinskim kosama, koje se spuštaju prema rekama i potocima, bili su pogodni za njihovo formiranje. Dosadašnja saznanja o prostornoj i društvenoj organizaciji rudarskih naselja pružaju nam ograničene mogućnosti za praćenje odnosa između prirodnog i izgrađenog okruženja. Iako precizniji podaci i dalje nedostaju, zagađenje životne sredine, usled kontaminacije zemljišta, voda i vazduha, između ostalog povezuje se sa topionicama postavljanim u neposrednoj blizini. Zahvaljujući istraživanjima problema koje stvara moderna industrija, možemo steći uvid u uticaj prethodnih praksi rudarstva i obrade metala na okolinu i zdravlje ljudi.

Ključne reči: rudarstvo, topionice, srednji vek, Srbija, zagađenje, životna sredina

\section{Uvod}

Nekoliko vekova je prošlo otkako se na ovim prostorima razvijeno antičko rudarstvo ugasilo, do ponovnog uspona sa dolaskom nemačkih rudara Sasa. Još uvek nisu utvrđene tačne okolnosti njihovog dolaska, ali se zna da su polovinom XIII veka delovali u mestu Brskovo, u blizini Mojkovca (Ćirković, Kovačević-Kojić i Ćuk 2002, 21). Zahvaljujući napretku, koji se ogleda pre svega u eksploataciji plemenitih metala (srebra, bakra i olova), dolazi do formiranja i drugih rudarskih i trgovačkih centara (Karta 1). Sve do tada, tokom ranog srednjeg veka i u vreme vladavine prvih Nemanjića, razvijala se metalurgija gvožđa i njene zanatske delatnosti (Čremošnik 1977; Fostikov 2012). Veličina, intenzitet i bogatstvo srebronosnih rudnika, uz Novo Brdo kao najveći, uticali su da prostor Balkana tokom XIV i prve polovine XV veka zauzme nesumnjivo važno mesto u ukupnoj evropskoj proizvodnji (Ćirković, Kovačević-Kojić i Ćuk 2002, 119).

Termin rudarstvo u srednjem veku obuhvatao je dva različita proizvodna $\mathrm{i}$ prostorna kompleksa, koji su s jedne strane podrazumevali eksploataciju rude 


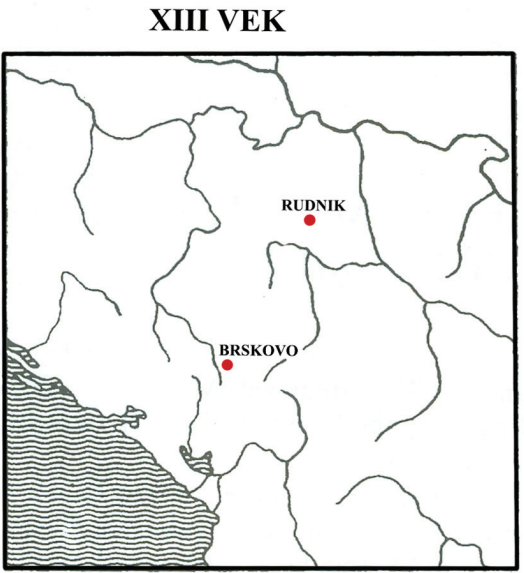

XIV (1350-1400)

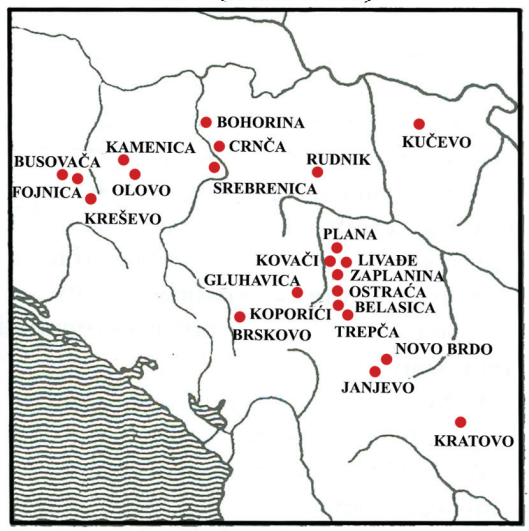

XV (1450-1500)

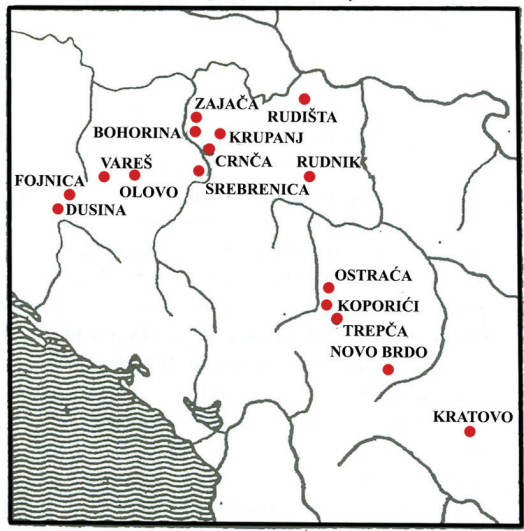

XIV (1300-1350)

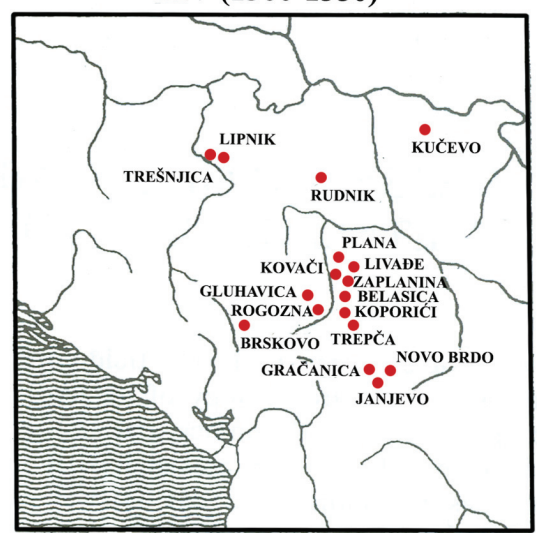

XV (1400-1450)

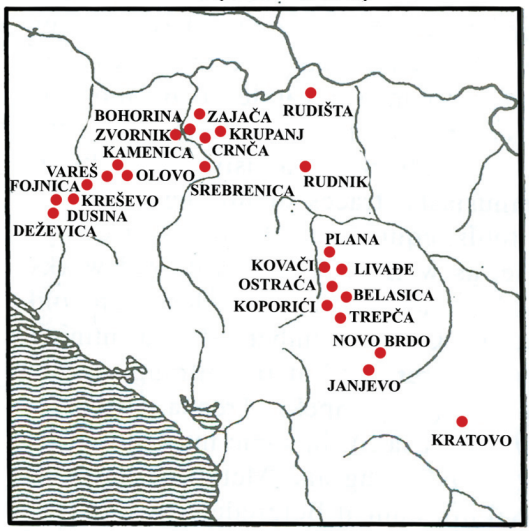

XVI VEK

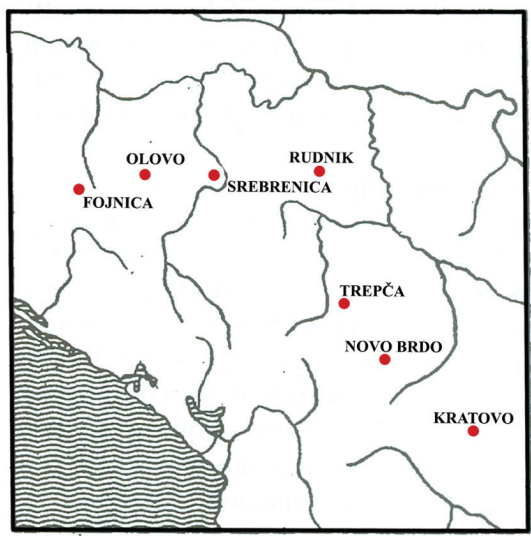

Karta 1. Hronologija pojave pojedinih rudnika od XIII do XVI veka (modifikovano prema Mrkobrad 1995) 
prateći ležišta minerala, a sa druge strane preradu, koja je morala biti prilagođena terenu (Ćirković, Kovačević-Kojić, Ćuk 2002, 49). Stari radovi očuvali su se kao oblici površinske i podzemne eksploatacije, odnosno tzv. svrtnjevi ili pinge (zarušena okna vertikalnih hodnika) i potkopi (zarušena okna horizontalnih hodnika). Različitog oblika (kružni, levkasto-izduženi) i veličine, površinski sistemi su teško uočljivi na terenu bez sondažnih provera, dok se uz podzemne često javlja „kiža“, koja predstavlja usitnjenu drobinu sa kiselom, obojenom vodom (Bogosavljević 1990, 40; Bogosavljević 1989, 92). Velike količine šljake (za koju se koriste i termini zgura, troska, šlakna, otopina) i delovi objekata, u vidu grumenja zapečene zemlje sa tragovima profilacije, upućuju na metalurški kompleks, odnosno topionice sa pećima (Bogosavljević 1989, 92). Procesi prerade u zavisnosti od korišćene tehnologije, obavljani su na promajnim proplancima uz snagu vetra i pored reka i potoka, uz snagu vodenog toka. Topografski položaj šljakišta je tako korišćen kao metoda za razlikovanje antičkih od srednjovekovnih topionica, jer se pretpostavilo da je u srednjem veku energija vode korišćena za pokretanje mehova, koji su raspaljivali vatru u pećima (Simić 1951, 28-29). Rudarski trgovi, kao administrativni centri, pojavljivali su se na teško pristupačnim i stranputnim mestima, koja ubrzo postaju raskrsnice važnih puteva.

Postavlja se pitanje da li je sa rastom eksploatacije rastao stepen kontaminacije i zagađenja životne sredine, kao rezultat nepravilnog kopanja, prakse topljenja ili odlaganja otpada. Problemi koji se susreću, poput emisija iz topionica dešavali su se i još uvek se dešavaju širom sveta (Lottermoser 2010, 22). U radu će se razmatrati na koji način se rudarstvo može dovesti u vezu sa narušavanjem okoline i zdravlja ljudi, na primeru srednjovekovnih rudarskih područja koja su bila predmet kako istoriografskih, tako i arheoloških i geoloških istraživanja.

\section{Prostorna i društvena organizacija rudarskih naselja}

Traganje za ležištima rude vodilo je srednjovekovne rudare daleko iznad ravnica, u šumske planinske predele. Izbor mesta gde će se razvijati postrojenja za obradu rude zavisio je s jedne strane od same eksploatacije, kako bi se smanjili troškovi transporta, dok je s druge strane blizina šuma i bogatstvo vodenih tokova, kao izvora energije i sredstva za ispiranje, bila od velike važnosti (Ćirković, Kovačević-Kojić i Ćuk 2002, 57). Istraživanja oblasti oko rudnika Kiževak na Kopaoniku, poznatog po depozitima olova, cinka i gvožđa, daju sliku jednog srednjovekovnog pejzaža. Prirodne odlike brdovitog terena, nadmorske visine 600-1000 m manifestovane su bogatstvom šuma četinara, bukve i hrasta i velikog broja bujičnih i stalnih potoka (V. Bogosavljević, Mrkobrad i D. Bogosavljević 1988, 28). U dolinama kopaoničkih reka (Brzećka, Duboka, Samokovka, Rudnička, Bela i Velika reka) i župnih regija, pokazalo se da svojstva ovih prirod- 
nih celina utiču na organizaciju topionica, za čiji rad blizina rudnog izvora (Oštra Čuka, Rudnica, Bećirovac, Suvo Rudište) nije morala biti dosledno ispoštovana (Bogosavljević-Petrović 2006, 78). Na području Rudnika najbrojnija, ali relativno mala šljakišta zabeležena su u dolinama reka (Jasenica, Majdanska reka) i ona mogu biti udaljena više kilometara od rudnih nalazišta, dok su najveća šljakišta u jarugama ili terasastim delovima padina smeštena u neposrednoj blizini starih radova (Vuković 1992, 135-136). Kroz toponomastiku današnjih naselja možemo pretpostaviti gde su vršeni eksploatacioni i topionički radovi, koji upućuju na stara okna, kola ili samokove ili prostor mokre separacije rude (plakaonice). Tako na padinama Kopaonika srećemo Samokovsku i Viganjsku reku, Kiževak i Rupčine (Simić 1975b; V. Bogosavljević, Mrkobrad i D. Bogosavljević 1988), u okolini Novog Brda Nišino kolo, Srebrno kolo i Kačikolo (Savić 1956), dok se na Goliji nalazi Plakaonička reka (Simić 1975a). Ovakvi nazivi pojavljuju se u gotovo svim rudarskim područjima, upućujući istovremeno i na period saskog rudarenja (Saška reka i Saški do u istočnoj Srbiji) (Mrkobrad 1997).

Kako se staro rudarstvo savremenim kopovima destruktivno razaralo, registrovanje sačuvanih ostataka od strane geologa i rudarskih inženjera bilo je veoma potrebno. Sistematski prikupljana terenska građa, koja je obuhvatala kartiranje starih okana, šljakišta, naselja, utvrđenja iz gotovo svih rudarskih oblasti Srbije, omogućila je da se bar delimično sagleda prostor do kog su bili spremni da idu rudari u potrazi za sirovinama ili na kojoj udaljenosti su vršili njihovu preradu (Simić 1951, 1958, 1971, 1975). Sa druge strane, arheometalurška istraživanja na planinama Rudnik i Kopaonik i na prostoru istočne Srbije dala su značajan doprinos boljem poznavanju srednjovekovnih rudarskih objekata, koji su poslužili kao osnova za rekonstrukciju jamskih i topioničkih radova (Mrkobrad i Bogosavljević 1988; V. Bogosavljević, Mrkobrad i D. Bogosavljević 1988; Bogosavljević-Petrović 1995; Mrkobrad i Durlić 1995). ${ }^{1}$ Rekognosciranja potesa oko rudnika Kiževak i Suvo Rudište pokazala su postojanje velikog broja svrtnjeva (pingi), kao i nepodgrađenih i podgrađenih rudarskih prostorija, tipa horizontalnih i kosih hodnika i okana. (V. Bogosavljević, Mrkobrad i D. Bogosavljević 1988). Pronađeni arheološki materijal pružio je podatke o načinu podgrađivanja, kojim se sprečavalo zarušavanje prostorija usled podzemnog pritiska. Za podgradu je korišćena obrađena drvna građa (oblice i cepane daske) i okrajci, koji su formirali četvrtaste i trapezoidne okvire (V. Bogosavljević, Mrkobrad i D. Bogosavljević 1988, 29). Potvrdu o potrebi rudara za obezbeđivanjem sigurnih radova pokazala su i istraživanja na lokalitetu Trnovite lazine na planini Rudnik. Prilikom izgradnje lokalnog puta konstatovan je eliptični

${ }^{1}$ Projekat „Rudarenje u praistoriji, antici i srednjem veku” sproveo je Arheološki institut u Beogradu, pod rukovodstvom B. Jovanovića, u okviru koga je Narodni muzej u Kraljevu, pod rukovodstvom V. Bogosavljević-Petrović realizovao posebnu temu projekta „Spomenici starog rudarstva i metalurgije na Kopaoniku”. 
otvor vertikalnog rudarskog okna. Iskopavanjima je potom otkrivena pristupna rampa sa potpornim zidom, koja se kaskadno spuštala ka samom ulazu u okno. Iako funkcija objekta nije do kraja razjašnjena, pretpostavka je da se radi o ventilacionom oknu, izvoznoj platformi ili otvoru za ispumpavanje podzemnih voda. Svakako postojanje pristupne rampe upućuje na siguran prilaz određenom rudarskom objektu (Mrkobrad i Bogosavljević 1988, 42-43). Srednjovekovni objekti sa metalurškom aktivnošću iskopavani su u dolini reke Jasenice na Rudniku. Na lokalitetu Pumpna stanica otkrivena je ugljarska kalotasta peć, očuvanih dimenzija 2,60 x 1,10 m. U njene zidove ugrađeni su blokovi zgure, različitih dimenzija, koji upućuju na metaluršku aktivnost u neposrednoj blizini (Mrkobrad i Bogosavljević 1988, 46-47). Na manjem platou koji se uzdiže na svega 6-8 m od ušća Javorića, podignute su složene instalacije namenjene topljenju rude. U prilog postojanju topionice na ovom mestu govore velike količine zgure, tragovi jakog gorenja i ostaci zidova rađeni u kamenu. Ova dva objekta verovatno su bila deo većeg metalurškog sistema, koji je sadržao mesta za pripremu (ugljarska peć) i topljenje rude (same peći). Prikupljeni arheološki materijal čini grnčarija opredeljena u period XIV i XV veka, ali i nakon pada Rudnika pod tursku vlast (Mrkobrad i Bogosavljević 1988, 48-50). ${ }^{2}$ Slične vrste posuda, koje odlikuje zeleno gleđosani premaz i zgrafito ornamentika, pronalažene su i prilikom istraživanja srednjovekovnih naseobinskih objekata nedaleko od varošice Rudnik. Stoga bi ovi metalurški objekti bili udaljeni oko 2 km od nekadašnjeg naselja, a najbliži ostaci starih radova na padinama Malog Šturca oko $1 \mathrm{~km}$. U dolini Majdanske reke ostaci naselja registrovani su na više pozicija (Madas 1988), od kojih se na manje od $1 \mathrm{~km}$ nalaze tragovi topioničkih aktivnosti (šljaka). Na udaljenosti od $1 \mathrm{~km}$ šljaka se javlja u dolini Rudnice na Brskovu (Gogić 2010, 201), dok je u Srebrenici zabeleženo postojanje unutar samog naselja (Ćirković 1997, 87).

Od početka osnivanja rudarskih trgova stanovništvo je bilo socijalno, etnički i verski heterogeno. Najbrojniju kategoriju činili su rudari, tačnije svi oni koji su učestvovali u procesima vađenja i prerade rude. Kao dobri poznavaoci rudarenja, Sasi su organizovali proizvodnju i ujedno bili vlasnici delova rudnika, da bi vremenom domaći ljudi preuzimali tu ulogu (Kovačević-Kojić 1992, 35-36). Pored zanimanja vezanih za rudarstvo brojni su bili trgovci iz Primorja i susednih zemalja. Među njima najviše su se isticali Dubrovčani, koji postepeno u blizini pojedinih rudnika formiraju svoje naseobine. Unapređenje rudarstva i trgovine podstaklo je razvijanje drugih delatnosti, poput zanatstva, poljoprivrede, umetnosti (Kovačević-Kojić 1992, 40-45). Građenje pravoslavnih crkava i formiranje katoličkih parohija unutar ovih centara svedoči o verskoj raznolikosti. Domaće stanovništvo podizalo je svoje crkve, koje se u istorijskim izvorima slabo pominju, a za koje se zna zahvaljujući arheološkim istraživanjima (Rudnik,

${ }^{2}$ Dokumentacija Arheološke zbirke Filozofskog fakulteta u Beogradu. 
Novo Brdo) (Radičević 2014; Popović i Bjelić 2018). Katoličke parohije bile su predmet istoriografskih i arheoloških proučavanja (Ćirković 1997, 243-251; Hrabak 1952, 1984), poput onih na Brskovu, Rudniku, Novom Brdu ili Plani (Živanović 2020; Radičević 2014; Bogosavljević-Petrović 2006). O urbanističkoj strukturi ovih centara nema puno podataka, pa se njihov izgled za sada može delimično rekonstruisati. U središtu naselja nalazio se trg, oko koga su se formirale radnje trgovaca i zanatlija. Kuće, smeštene u ulicama ili na samom trgu, bile su većinom građene od drveta, ali su postojale i kamene sa spratnom konstrukcijom (Ćirković, Kovačević-Kojić i Ćuk 2002, 129-130). Primeri i jednih i drugih objekata, međusobno udaljenih svega nekoliko desetina metara, otkriveni su na Rudniku (Radičević 2019). Takođe, navode se i zdravstvene ustanove, bolnice (Novo Brdo) i leprozoriji - skloništa za gubavce (Srebrenica, Fojnica), koji su verovatno smeštani na periferiji naselja. Neke vrste kanalizacionih sistema, koje čine odvodni kanali, prekriveni pločama, poznati su u Srebrenici (Ćirković, Kovačević-Kojić i Ćuk 2002, 131), a arheološka istraživanaja poslednjih godina potvrđuju prisustvo i na Rudniku. ${ }^{3}$ Složeno hidrotehničko postrojenje sa glinenim cevima i kamenim pokrivačem, koje je istovremeno korišćeno za dovođenje pitke i tehničke vode, otkriveno je u blizini rudarskog trga Plana (Mihailović 2014), a takva postrojenja zabeležena su i u okolini Koporića i Jelakca (Simić 1958, 376-378). Precizniji podaci o razmerama i organizaciji i dalje nedostaju, ali sve upućuje na to da se radi o otvorenim naseljima, zbijenog tipa. Položaj rudarskih trgova i okolnih rudnika bio je branjen utvrdama, postavljenim na dominantnim i strateški važnim pozicijama. Zaštitu su mogle da pružaju tvrđave (Brskovo, Ostrovica, Novo Brdo) (Radičević 2019; Popović i Simić 2020) ili pojedinačne kule-stražare (Plana, Zaplanina, Belasica) (Simić 1958; Bogosavljević-Petrović 1995). Podizanje ovakvih sistema odbrane imalo je za cilj da štiti lokalno stanovništvo u slučaju opasnosti, ali i da služi za skladištenje rudnih sirovina, kontrolišući istovremeno i glavne putne prilaze. Zanimljivo je da se koncentracije industrije u nekom gradu i eksploatacija rude u njegovoj blizini povezuju sa pojavom savremene urbanizacije, pa ne čudi zašto su rudarska naselja nesumnjivo uticala na proces urbanizacije srednjovekovne Srbije (Zarković 2019, 108).

\section{Odnos ljudi i okoline}

Praćenje odnosa između prirodnog i izgrađenog okruženja i lokalnog stanovništva smatra se mogućim, uprkos dinamičnosti promena koje su se dogodile u mnogim srednjovekovnim rudarskim centrima. Na pitanje kako su rudarske i topioničke delatnosti uticale na okolinu, odgovori se traže u

${ }^{3}$ Dokumentacija projekta Arheološka istraživanja na planini Rudnik, Muzeja rudničko-takovskog kraja. 
istorijskim, arheološkim, ekološkim izvorima. Kao glavni problemi navode se uništavanje pejzaža usled krčenja šuma (Iles 2015), kontaminacija zemljišta, voda i vazduha (Cembrzyński 2019), što je na kraju moglo da rezultira lošim zdravstvenim statusom stanovništva. Opisujući procese eksploatacije i prerade rude, Georgij Agrikola je polovinom XVI veka pisao o negativnim uticajima rudarstva na okolinu:

...Iskopavanjem rude se pustoše polja (...) Zbog rudnika se seče šuma jer postoji potreba za beskrajnim količinama drveta za podzemne radove, rudarsku opremu ili topljenje. A kad se šume i gajevi poseku, tada se ptice i zveri istrebe (...) Ispiranjem ruda se zagađuju reke i potoci i tako ubija riba. Stoga stanovnici u tim krajevima, zbog pustošenja polja, šuma, potoka i reka, imaju mnogo teškoća u nabavci neophodnih stvari za život. (Agricola 1950,8)

O zdravoj životnoj sredini u srednjovekovnoj Srbiji, sa bogatom florom i faunom, svedoče dela putopisaca i biografa. Putujući kroz Srbiju, Bertrandon de la Brokijer 1433. godine beleži zdrave i čiste vode, kao i rodnu i bogatu zemlju, sa gustim šumama (Brokijer 2002, 106-109). U opisima Konstantina Filozofa, biografa despota Stefana Lazarevića, navodi se da ova zemlja „toči med i mleko“, kao i da je posle zime vazduh „dobro prečišćen i krasan“ (Mišić 2007, 32). Značaj „pijenja dobre vode i udisanja svežeg vazduha“ za zdravlje ljudi ističe se u srednjovekovnim medicinskim spisima (Mišić 2007, 32). Ovakvi opisi prirode poklapaju se sa opštim istorijskim saznanjima o srpskim srednjovekovnim oblastima (Mišić 2007, 33), ali je postojanje nezdrave sredine takođe poznato. Zbog gomile nasutih slojeva rude i drvenog uglja, koji su paljeni i ostavljani da gore danima, stanovništvo je bilo izloženo štetnim gasovima. Takvi ekološki problemi primorali su Dubrovčane da se 1433. godine žale despotu Đurđu, od koga su tražili izmeštanje topionica i mesta gde se žari ruda van naselja u Srebrenici (Ćirković 1997, 87). Oni su dobili despotovu saglasnost, ali vlasnici izgleda nisu izvršili naređenje, pa je dubrovačka vlada morala diplomatski da interveniše (Ćirković, Kovačević-Kojić i Ćuk 2002, 58). Prolazeći ovim krajem sredinom XVII veka, putopisac Evlija Čelebi beleži zagađenje vode, navodeći ,jednu interesantnu rijetkost":

...Sredinom ove varoši teče mala voda koja se uliva u Drinu. Ona je bijela, a zove se srebrna voda. Ali to je neka prokleta voda. Izvire iz rudnika srebra. Stanovnici ove varoši, pijući tu vodu, većinom dobijaju na vratu gušu. Ona izaziva razne bolesti i unakažava muškarce i žene. (Čelebi 1967, 99)

Problemi zatrovanosti vodotokova početkom XVI veka, zbog prisustva nekoliko topionica na Majdanskoj reci, prouzrokovali su nedostatak pijaće vode u rudarskim naseljima u rejonu Majdana na Rudniku. Verovatno je i to bio jedan od razloga zašto se kod Dubrovčana Rudnik pročuo kao nezdravo mesto, koje treba izbegavati (Katić 2007, 134, 144). 
Koršćenje goriva $\mathrm{u}$ obliku drveta ili uglja bilo je neophodno za procese predtopljenja i topljenja rude. Zbog toga, kao i pretraživanja i vađenja rude, moglo je doći do povećane potražnje i krčenja šuma (deforestacija). Mala kružna udubljenja, nastala od rupa za pravljenje drvenog uglja registrovana su na planiskim predelima Kopaonika. Padine brda Gvozdac ispunjene su ovim stepenasto raspoređenim objektima, koji su u narodu poznati kao ,žežnice“ (Bogosavljević-Petrović 2006, 83). Kao posledica transformacija šuma javljalo se propadanje i erozija zemljišta, čime se vidljivo menjao pejzaž. Svakako i drugi ljudski faktori smatraju se uzrocima promena, uključujući poljoprivredu, stočarstvo, sukobe, povećanje stanovništva (Iles 2016, 1260). Svest o značaju ove vrste problema može se naslutiti kroz donošenje zakona kojima su regulisana prava seče. U članu 123 Zakonika cara Stefana Dušana, Sasima se zabranjuje da stiču imovinsko pravo na zemlji koja je iskrčena radi rudarske proizvodnje, kao i da se to pravo ne ustupa drugome. Ostavljano im je da mogu da seku šumu, nakon čega su je morali ostavljati pustu, da bi ponovo izrasla (Bubalo 2010, 194-195). Na ovaj način se vidi da država vodi računa o očuvanju prirodne sredine, štiteći prava vlasnika šuma i zemlje. Pronalaženje veze između rudarstva i promene pejzaža usmeravalo je istraživanja na arheometalurgiju (geologiju), gde je glavni fokus bio na kvantifikaciji potrošnje drveta u odnosu na procenjenu proizvodnju metala. Međutim, tačna procena zapremine šljake je složen poduhvat, imajući u vidu da su određene količine uklanjane i korišćene još u srednjem veku za izgradnju objekata (crkva i ugljarska peć na Rudniku) (Radičević, Đorđević i Cicović 2009, 15; Mrkobrad i Bogosavljević 1988, 46-47) ili lokalnih puteva (Simić 1971, 7). Primer je veliki plato u selu Karadak, koji nakon decenija uništavanja stare šljake deluje kao „mesečev pejzaž“ (Bogosavljević-Petrović 2006, 79). To mogu biti i neki od razloga zašto rezultati geoloških istraživanja starih šljakišta na Novom Brdu ukazuju na mnogo manji obim eksploatacije od pretpostavljenih količina (Savić 1952), što predstavlja veliko razmimoilaženje sa istorijskim podacima (Kovačević-Kojić 2013). Procena količine drvne mase upotrebljavane kao metaluško gorivo ispitivana je na primeru antičkih i srednjovekovnih srebronosnih rudnika u Šumadiji (Avala, Kosmaj i Rudnik). U prvobitno određenim zapreminama starih šljaka procenjivan je sadržaj kalijuma, koji je u šljaku dospeo preko goriva (drveta) prilikom topljenja (S. Vuković i M. Vuković 1988). Ustanovljeno je da površina posečenih šuma na Rudniku iznosi $60 \mathrm{~km}^{2}$ i da je njihova eksploatacija, zbog nepovoljne konfiguracije zemljišta, vršena u neposrednoj blizini topionica, na udaljenosti $1-4 \mathrm{~km}$. To je kasnije moglo da prouzrokuje bujice i razaranje šljakišta. Na području Avale, drvo je takođe korišćeno u neposrednoj okolini topionica, na udaljenosti oko $6 \mathrm{~km}$, na kojoj je posečeno $115 \mathrm{~km}^{2}$ šume. Daleko veća površina posečene šume od 944 $\mathrm{km}^{2}$ bila je tokom antičke eksploatacije Kosmaja, dok je prosečna udaljenost iznosila 17 km (S. Vuković i M. Vuković 1988, 488-489). Sa ciljem rekonstruk- 
cije stare metalurške tehnologije, proučavan je mineralni sastav i struktura šljake u različitim rudonosnim područjima (Vuković 1983; Savić 1956; Stojanović 1995). Olovno-cinkana šljakišta u Šumadiji, koja imaju gotovo identičan sastav rudnih mineralizacija i okolnih stena, bila su pogodna za poređenja. Posmatranjem morfoloških karakteristika pokušao se premostiti problem određivanja starosti, odnosno razgraničenja antičkih od srednjovekovnih depozita. Došlo se do zaključka da su procesi dobijanja srebra i olova kod antičkih i srednjovekovnih metalurga bili slični u temperaturi topljenja $\left(\right.$ do $\left.1450^{\circ} \mathrm{C} / 1500^{\circ} \mathrm{C}\right)$, rudnoj šarži i gorivu (drvo/ugalj) (Vuković 1983, 72-73). Kao tehnološke razlike navode se: proces pretprženja (,roštovanja“), koji je tokom srednjeg veka verovatno proizašao iz sušenja rude pre topljenja, konstrukcija, položaj i veličina peći, kao i ritam topljenja rude (Vuković 1992, 141).

Opustošena životna sredina, težak fizički rad i prisustvo toksičnih supstanci u okruženju imali su određeni uticaj na zdravstveni status stanovništva. Iz Agrikolinog opisa znamo o bolestima sa kojima su se rudari susretali, kao i o načinima njihovog lečenja.

... zbog bolesti nekima slabe zglobovi, drugima stradaju pluća, nekima oči, a neke bolesti su i smrtonosne (...) prašina koja se stvara pri eksploataciji prodire u dušnik i pluća, zbog čega dolazi do poteškoća u disanju i bolesti koju Grci zovu astma (...) postoji i određena vrsta kadmijuma koji izjeda noge i ruke rudara, a oštećuje i pluća i oči. Zato za kopanje treba da se nabave ne samo čizme od sirove kože, već i rukavice do lakta, a na lice slobodne maske zahvaljujući kojima prašina neće doći u grlo, pluća i oči. (Agricola 1950, 214-215)

Jedna od mogućih metoda za istraživanje uticaja ovakvih uslova jeste analiza skeletnih ostataka. Pored osnovne morfometrijske i paleopatološke analize, bilo bi sprovedeno merenje olova, žive i arsena u kostima, koji su dokaz dugotrajnog unosa (Aufderheide and Rodriguez-Martin 1998, 316-322). Na ovom polju do sada se nije mnogo uradilo, a poznati su samo preliminarni rezultati antropoloških analiza iz rudarskih centara Brskovo i Rudnik. Sa lokaliteta Doganjice na Brskovu potiču skeletni ostaci, koji predstavljaju sekundarnu sahranu individua iz obližnje nekropole. Prisutni osteološki materijal ukazuje da je odrasla populacija kod oba pola bila izložena težim fizičkim aktivnostima, zbog čega su imali problema sa osteoartritisom. Kod dečijijh individua sitne lezije na kostima lobanje sugerišu na anemiju i prisustvo metaboličkih oboljenja, prouzrokovanih lošijim načinom života (Vulović 2019, 182-185). Antropološka analiza skeleta individua otkrivenih prilikom iskopavanja crkve, na lokalitetu Madžarsko brdo na Rudniku takođe ukazuje na probleme sa osteoartritisom i drugim poremećajima, na koje su mogli da utiču teška fizička aktivnost i lošiji higijenski uslovi (Vulović i Bizjak 2019, 105-106). Nažalost, propuštena je prilika da se urade fizičko-antropološke analize skeletnog materijala sa nekropola Novog Brda, gde je tokom istraživanja crkve Svetog Nikole otkriveno 970 grobova. U ovaj broj nisu uključeni pore- 
mećeni i rasuti skeletni ostaci, tako da se može steći samo delimičan uvid u broj sahranjenih (Popović i Bjelić 2018, 155). Novobrdski skeletni materijal posebno je zanimljiv imajući u vidu da su u nekoliko grobova otkrivene rudarske alatke, koje su pohranjene zajedno sa pokojnicima (Bogosavljević 1995, 262).

\section{Uticaj starih i savremenih radova na okolinu Rudnika i Srebrenice}

Rudarenjem i metalurškom preradom stvara se otpadni rudni materijal, koji predstavlja nepoželjni nusprodukt, bez ekonomske i tržišne vrednosti. Njegovim odlaganjem povećava se rizik od zagađenja, jer se vremenom mogu pokrenuti spontane hemijske reakcije usled reaktivnosti u površinskim uslovima (Lottermoser 2010, 40-43). Uticaji ovih rudnih otpada u/van neposrednog okruženja obično pokazuju blisku vezu između tekuće i/ili ranije rudarske aktivnosti i ozbiljnog zagađenja. Studije savremenih istraživanja bi kao takve mogle da ukažu na potencijalne izvore zagađenja i tokom srednjovekovnog perioda.

Tokom ispitivanja procesa zagađenja na planini Rudnik, analizirana je uloga aktivnih i napuštenih odlagališta, kao i uloga stare (srednjovekovne) šljake. Uzorkovanjem različitih nosilaca zagađenja istraživanja su sprovedena na potesima oko današnje varošice Rudnik, na padinama Malog i Srednjeg Šturca, kao i u dolinama već pomenutih reka - Majdanske i Jaseničke. Rezultati ukazuju na povišene koncentracije potencijalno toksičnih elemenata (arsena, olova, nikla i hroma). Kao prvi izvor zagađenja zemljišta u neposrednoj blizini odlagališta navodi se raspadanje sulfida u otpadnom materijalu sa odlagališta, uticaji otpadnih voda i matičnih i/ili okolnih stena (Zdravković 2020, 101; Zdravković et al. 2017). Raspadanje srednjovekovne šljake, prikupljane u okolini gornjeg toka Jasenice, čini drugi izvor zagađenja u uzorcima zemljišta i voda koji su udaljeni od odlagališta i samog ležišta. Razlog je navedeno korišćenje stare šljake u nasipanju lokalnih puteva (Zdravković 2020, 102; Zdravković et al. 2020). Zbog povišenih vrednosti toksičnih elemenata, posebno arsena i olova, ustanovljeno je da se voda iz potoka i reka na Rudniku može smatrati zagađenom, a samim tim i neupotrebljivom za piće i navodnjavanje zemljišta, odnosno zalivanje poljoprivrednih kultura (Zdravković 2020, 101). Integracija rezultata ovih mineraloških i hidrohemijskih ispitivanja može poslužiti kao studija slučaja i za ostala olovno-cinkana ležišta u celoj šumadijskoj metalogenetskoj oblasti.

Kako bi se ustanovio uticaj teških metala na životnu sredinu, u okolini rudarskog i metalurškog područja $(\mathrm{Pb}-\mathrm{Zn})$ Srebrenica vršena su istraživanja u izvorskim vodama. Usled nekadašnje rudarske aktivnosti stvara se odliv kisele vode iz rudnika (acid mining drainages), koja sadrži sulfide gvožđa i druge elemente, uključujući i arsen. Kao lako rastvorljivi, oni potom dolaze u kontakt sa površinskim i podzemnim vodama. Proces rastvaranja minerala proučavan je 
na primeru lekovite vode Crni Guber, koja nastaje u starim (rimskim i/ili srednjovekovnim) rudnicima. Ustanovljeno je da voda sadrži metale poput olova, cinka, gvožđa, ali i veoma visoke procente arsena. Očekivano je da ona bude veoma toksična, zbog velike koncentracije arsena, međutim, u kombinaciji sa gvožđem ona postaje korisna za lečenje anemije i kožnih bolesti. Istraživanja ukazuju da se u banji Crni Guber koristi samo jedan deo izvorske vode, dok se ostatak slobodno uliva u potok, predstavljajući potencijalni izvor zagađenja arsena nizvodno (A. Dangić i J. Dangić 2007, 220-221).

\section{Zaključak}

Pregledom dosadašnjih istraživanja rudarstva srednjovekovne Srbije otvaraju se mogućnosti za razmišljanje o uticaju na životnu sredinu. Kako su percepcije okoline i promena u okruženju oblikovane socijalnim i kulturnim očekivanjima i sećanjima, istorijsko tumačenje „,̌itanjem pejzaža“ u osnovi može biti subjektivno (Iles 2015, 1224). Prateći dva različita izvora, 1433. godine u Srbiji nailazimo na zdrave i čiste vode, sa šumovitom i rodnom zemljom, i zagađen vazduh od koga ne može da se živi. Blizina rečnih tokova i šuma bila je osnovno svojstvo prirodnih celina, koje su obezbeđivale neophodnu energiju i gorivo za metalurške aktivnosti. Velike količine drveta korišćene su za podgrađivanje podzemnih rudarskih hodnika, čime se osiguravao rad od potencijalnog urušavanja. Blizina topionica, koja je bila jedan od uslova za formiranje naselja, izazivala je zabrinutost radnika i stanovnika rudarskih oblasti. Problemi zagađenja, zbog ispuštanja toksičnih supstanci u vodu i vazduh, javljali su se u Srebrenici i na Rudniku. Dosadašnji arheološki podaci teško da mogu potkrepiti ova istorijska saznanja, s obzirom na činjenicu da su na svega nekoliko nalazišta istraženi ostaci topionica, od kojih se samo oni u dolini Jasenice na Rudniku pouzdano pripisuju srednjovekovnom periodu. O trovanju teškim metalima kod stanovnika Rudnika ili Brskova u ovom trenutku se ne može govoriti bez sprovedenih hemijskih analiza, bez obzira na to što antropološka slika ukazuje na lošiji zdravstveni status. Sa druge strane, današnje znanje o teškim metalima i njihovom efektu može pružiti uvid u delovanje prethodnih praksi rudarstva na okolinu i zdravlje ljudi. Merenje nivoa olova u krvi kod savremene dečije populacije, koja je naseljena u blizini rudarsko-metalurškog kompleksa Zajača, ujedno i poznatog srednjovekovnog rudarskog centra, ukazuje na korelaciju između povišenih koncentracija i razdaljine (blizine) topionice (Matić, Dejanović i Đonović 2018). Rezultati savremenog zagađenja nude moguće izvore, zbog kojih je na Rudniku početkom XVI veka, odnosno u Srebrenici tokom XV i XVII veka bilo opasno živeti. Proučavanje veze metalurgije sa životnom sredinom u prošlosti trebalo bi da okrene buduće arheološke radove mnogo više prema interdisciplinarnosti, čime bi se uz prikupljanje kulturnih i ekoloških dokaza stvorila šira slika o kvalitetu života u rudarskim regionima. 


\section{Istorijski izvori}

Agricola, Georgius. 1950. De Re Metallica Translated from First Latin Edition of 1556 by Herbert Clark Hoover and Lou Henry Hoover. New York: Dover Publications.

De La Brokijer, Bertrandon. 2002. Putovanje preko mora kroz Palestinu, Malu Aziju, Srbiju i Francusku, preveo Miodrag Rajičić. Beograd: Čigoja.

Čelebi, Evlija. 1967. Putopis - odlomci o jugoslovenskim zemljama, preveo Hazim Šabanović. Sarajevo: Svjetlost.

\section{Literatura}

Aufderheide, Arthur and Conrado Rodriguez-Martin. 1998. Human Paleopathology, New York: Cambridge University Press.

Bogosavljević, Dragan. 1990. „Srpsko srednjovekovno rudarstvo - istraženost i vidovi uključenja arheologije“. Glasnik Srpskog arheološkog društva 6: 36-44.

Bogosavljević, Dragan. 1995. „Medieval Mining Tools from the Belgrade National Museum Collection“. In Ancient Mining and Metallurgy in Southeast Europe, edited by Petar Perović and Slađana Đurđekanović, 251-264. Bor and Belgrade: Museum of Mining and Metallurgy and Archaeological Institute.

Bogosavljević, Vera. 1989. „Uvod u rudarsku arheologiju na Kopaoniku, oblici starog rudarstva i metalurgije“. Glasnik Srpskog arheološkog društva 5: 86-93.

Bogosavljević, Vera, Dušan Mrkobrad i Dragan Bogosavljević. 1988. „Istraživanje srednjovekovnog rudarstva na zapadnom Kopaoniku (okolina Kiževaka)“. Naša prošlost 3: 9-45.

Bogosavljević-Petrović, Vera. 1995. „Arheometalurški kompleksi na Kopaonikku (metodi i problemi proučavanja), Glasnik Srpskog arheološkog društva 10: 58-71.

Bogosavljević-Petrović, Vera. 2006. „Kontinuitet metalurgije u dolini Ibra“. Naša prošlost 6: 63-89.

Bubalo, Đorđe. 2010. Dušanov zakonik. Beograd: Zavod za udžbenike i Službeni glasnik.

Cembrzyński, Paweł. 2019. „The ecology of mining. Human-environmental relations in the Medieval and Early Modern mining in Central Europe“. Kwartalnik Historii Kultury Materialnej 67 (1): 17-39.

Čremošnik, Irma. 1977. „Ranoslovensko naselje Jazbine u Batkoviću kod Bijeljine“. Godišnjak ANUBIH XV (13): 227-304.

Ćirković, Sima. 1997. Rabotnici, vojnici, duhovnici (Društva srednjovekovnog Balkana). Beograd: Equilibrium.

Ćirković, Sima, Desanka Kovačević-Kojić, Ruža Ćuk. 2002. Staro srpsko rudarstvo. Beograd: Vukova zadužbina i Novi Sad: Prometej.

Dangić, Adam and Jelena Dangić. 2007. „Arsenic in soil environment in central Balkan Peninsula southeastern Europe: occurence, geochemistry, and impacts". Trace Metals and other Contaminants in the Environment, 9, 207-236.

Fostikov, Aleksandra. 2012. „Kovački zanat na tlu srednjovekovne Srbije“. Beogradski istorijski glasnik III: 105-126.

Gogić, Miljan. 2010. „Rudarska proizvodnja u srednjovjekovnom Brskovu“. Istorijski zapisi 1/2010: 195-213. 
Hrabak, Bogumil. 1952. „Dubrovačka naseobina u kopaoničkom rudniku Belom Brdu“. Ogledi: 55-56.

Hrabak, Bogumil. 1984. „Rudnik pod Šturcem I njegova dubrovačka naseobina“. Zbornik Narodnog muzeja u Čačku 14: 5-78.

Iles, Louise. 2016. „The role of metallurgy in transforming global forests“. Journal of Archaeological Method and Theory 23, 1219-1241.

Katić, Srđan. 2007. „Rudnik pod osmanskom vlašću u XV i XVI veku“. Istorijski časopis LV, 133-155.

Kovačević-Kojić, Desanka. 1992. „Društvena struktura rudarskih gradova“. U Socijalna struktura srpskih gradskih naselja (XII-XVIII vek), uredili Jovanka Kalić i Miroslav Čolović, 35-47. Smederevo i Beograd: Muzej u Smederevu i Odeljenje za istoriju Filozofskog fakulteta u Beogradu.

Kovačević-Kojić, Desanka. 2013. „O sastavu i obradi metala iz srpskih srednjovekovnih rudnika“. Zbornik radova Vizantološkog instituta L, 853-862.

Lottermoser, Bernd. G. 2010. Mine Wastes - Characterization. Treatment and Environmental Impacts, Third Edition, Heidelberg: Springer-Verlag Berlin.

Matić, Branislava, Snežana Dejanović i Nela Đonović. 2018. „Blood Lead Levels in Children Living Close to the Antimony and Lead Mining-milling-smelting Complex in Serbia“. Tehnika 73(3): 435-443.

Mihailović, Tatjana. 2014. „Plana Water Supply - Medieval Technical Enterprise“. Archaeotechnology: Studying Technology from Prehistory to the Middle Ages, edited by Selena Vitezović and Dragana Antonović, 295-314. Belgrade: Serbian Archaeological Society.

Mišić, Siniša. 2007. Korišćenje unutrašnjih voda u srpskim zemljama srednjeg veka. Beograd: Utopija.

Mrkobrad, Dušan. 1995. ,Research of the medieval mining and metallurgy in the Rudnik mountain“. In Ancient Mining and Metallurgy in Southeast Europe, edited by Petar Perović i Slađana Đurđekanović, 241-250. Bor and Belgrade: Museum of Mining and Metallurgy and Archaeological Institute.

Mrkobrad, Dušan. 1997. „Srednjovekovno rudarstvo na prostoru istočne Srbije“. U Arheologija istočne Srbije, uredio Miroslav Lazić, 151-161. Beograd: Filozofski fakultet, Centar za arheološka istraživanja.

Mrkobrad, Dušan i Dragan Bogosavljević. 1988. „Istraživanje srednjovekovnog rudarstva i metalurgije na Rudniku“. Zbornik radova Narodnog muzeja u Čačku XVIII: 37-56.

Mrkobrad, Dušan i Paun Es Durlić. 1995. „Arheometalurška istraživanja na Prauriji“. Glasnik Srpskog arheološkog društva 10: 79-88.

Popović, Marko i Gordana Simić. 2020. Utvrđenja srednjovekovnog grada Novog Brda. Beograd: Republički zavod za zaštitu spomenika culture.

Popović, Marko i Igor Bjelić. 2018. Crkva Svetog Nikole - Katedrala Novog Brda, Beograd: Republički zavod za zaštitu spomenika kulture.

Radičević, Dejan. 2014. „U potrazi za srednjovekovnim Rudnikom“. U Rudnik, šapat visi$n a$, uredili Borisav Čeliković i Milojko Knežević, 285-312. Beograd: Službeni glasnik.

Radičević, Dejan. 2019. „Arheološka svedočanstva o najstarijim rudarskim trgovima srednjovekovne Srbije“. U Urbanizacija u istočnoj i jugoistočnoj Evropi, uredili Sr- 
đan Rudić i Aleksej Aleksandrovič Gordin, 63-87. Beograd i Nižnji Novgorod: Istorijski institut u Beogradu i Državni institut za arhitekturu i građevinu (NNGASU).

Radičević, Dejan, Jelena Đorđević i Ana Cicović. 2009. „Preliminarni rezultati arheoloških istraživanja na Rudniku u 2009. godini“. Zbornik radova muzeja rudničko-takovskog kraja 5, 7-19.

Savić, Miron. 1956. „Šljakišta na Novom Brdu i Kačikolu“. Starinar 5-6: 283-294.

Simić, Vasilije. 1951. Istorijski razvoj našeg rudarstva. Beograd: Izdavačko - štamparsko preduzeće Saveta za energetiku i ekstraktivnu industriju Vlade FNRJ.

Simić, Vasilije. 1958. „Rejonizacija i karakteristike srednjovekovne rudarske delatnosti u oblasti Kopaonika“. Vesnik zavoda za geološka i geofizička istraživanja 19: 357-393.

Simić, Vasilije. 1971. „Rudarska prošlost Rudničke planine u Šumadiji“. Rudarski glasnik 6: 1-17.

Simić, Vasilije. 1975a. „Staro rudarstvo gvožđa Golije, Troglava, Čemerna, Gluhe Vasi i Kušurmlije“. Rudarski glasnik 14: 1-10.

Simić, Vasilije. 1975b. ,Rudarstvo gvožđa u kopaoničkoj oblasti“. Rudarski glasnik 14: 77-87.

Stojanović, Dobrica. 1995. Mineralni sastav starih šljaka sa Kopaonika, Glasnik Srpskog arheološkog društva 10: 72-77.

Vuković, Sofija. 1983. „Mineralne asocijacije starih olovno-cinkanih šljaka u Šumadiji“. Glasnik prirodnjačkog muzeja, Serija A (38): 11-83.

Vuković, Sofija. 1992. „Rekonstrukcija drevne metalurške tehnologije na osnovu mineralnih asocijacija starih šljaka“. U Arheologija i prirodne nauke, uredio Dragoslav Srejović, 133-142. Beograd: SANU.

Vuković, Sofija i Milan Vuković. 1988. „Procena potrošnje drveta kao metalurškog goriva u starom i srednjem veku na primeru srebronosnih rudnika u Šumadiji“. Geološki anali Balkanskog poluostva 51, 481-491.

Vulović, Dragana. 2019. „Preliminarna antropološka analiza sa lokaliteta Brskovo Doganjice“. Nova antička Duklja X, 170-185.

Vulović, Dragana i Dragica Bizjak. 2019. „Antropološka analiza skeletal sa lokaliteta Madžarsko brdo“. U Rudnik 1 - Istraživanja srednjovekovnih nalazišta (2009 - 2013.godina), uredili Dejan Radičević i Ana Cicović, 93-118. Gornji Milanovac: Muzej rudničko-takovskog kraja.

Zarković, Božidar. 2019. „Pojava urbanih aglomeracija na tlu srednjovekovne Srbije“. U Urbanizacija u istočnoj i jugoistočnoj Evropi, uredili Srđan Rudić i Aleksej Aleksandrovič Gordin, 101-116. Beograd i Nižnji Novgorod: Istorijski institut u Beogradu i Državni institut za arhitekturu i građevinu (NNGASU).

Zdravković, Alena. 2020. „Mehanizam formiranja sekundarnih minerala na odlagalištima $\mathrm{Pb}-\mathrm{Zn}$ rudnika Rudnik i njihov uticaj na životnu sredinu“ Doktorska dis. Rudarsko - geološki fakultet, Univerzitet u Beogradu.

Zdravković, Alena, Vladica Cvetković, Aleksandar Pačevski, Aleksandra Rosić, Kristina Šarić, Vesna Matović and Suzana Erić. 2017. „Products of oxidative dissolution on waste rock dumps at the $\mathrm{Pb}-\mathrm{Zn}$ Rudnik mine in Serbia and their possible effects on the environment“". Journal of Geochemical Exploration 181: 160-171.

Zdravković, Alena, Vladica Cvetković, Kristina Šarić, Aleksandar Pačevski, Aleksandra Rosić and Suzana Erić. 2020. „Waste rocks and medieval slag as sources of 
environmental pollution in the area of the $\mathrm{Pb}-\mathrm{Zn}$ Mine Rudnik (Serbia)“. Journal of Geochemical Exploration 218: 106629.

Živanović, Miloš. 2020. „Nova saznanja o srednjovjekovnom Brskovu“. Nova antička

Duklja XI: 113-130.

Mirko Vranić

Laboratory of Bioarchaeology, Department of Archaeology, Faculty of Philosophy, University of Belgrade

The Impact of Medieval Mining upon the Environment of the Central Balkans

The paper examines the impact of medieval mining upon the environment, based upon the present state of the historiographical, archaeological, and geological research. By the middle of the $13^{\text {th }}$ century a massive increase in the exploitation of precious metals is noted, inducing the appearance of settlements in the vicinity of the locations of extraction and production of ores. The problems of water and air pollution occurred, raised by the operation of smelteries inside these settlements or in their immediate vicinity. Although the presence of slag indicates certain metallurgical activity, it is hard to discern the precise purpose and the period of their activity without archaeological excavations. The increase in demand for fuel may have induced deforestation, so the rights to exploit forests were legally regulated. The scope of wood exploitation in the region of Šumadija has been judged by the research estimating the presence of potassium in the previously registered old slag deposits. It is hard to discern the general health status of the inhabitants of the mining regions, since a small portion of skeletal material is examined, not including the one from the most important mining center of Novo Brdo. The anthropological analysis indicates the problems caused by hard physical activity and poor hygiene. The present knowledge on the influence of heavy metals indicates the impact of past mining practices upon the environment and human health. Decomposition of sulphides in the discard deposits and old slag, as well as the leak of acid waters from old shafts, still affect the present pollution of water and soil in the vicinity of mining centres such as Rudnik and Srebrenica. These same reasons may have presented dangers for the population living there during the period of $15^{\text {th }}$ to $17^{\text {th }}$ century. The future archaeological research, with the inclusion of other disciplines, will bring more detailed understanding of the relationship between people and their environment in the mining regions of the Medieval Serbia.

Keywords: mining, smelteries, Middle Ages, Serbia, pollution, environment 


\section{Influence de l'exploitation minière médiévale sur l'environnement}

Basé sur les recherches historiques, archéologiques et géologiques menées jusqu'à présent, ce travail étudie l'influence de l'exploitation minière médiévale sur l'environnement. Vers la moitié du XIII ${ }^{\mathrm{e}}$ siècle l'exploitation des métaux rares connaît un grand progrès provoquant l'apparition des habitats à proximité des lieux de production et de traitement des minerais. Les problèmes de pollution des eaux et de l'air apparaissaient à cause de l'activité des fonderies à l'intérieur des habitats ou bien dans leur voisinage immédiat. La présence de scories, indiquant l'existence des fonderies, servait à analyser la relation de leur distance bien qu'on puisse difficilement parler de la période précise d'utilisation sans fouilles. Une demande augmentée pour les combustibles a pu provoquer la déforestation et c'est pour cette raison que les droits de coupe étaient réglés par les lois. On connaît le volume de consommation du bois sur le territoire de Šumadija des recherches estimant la teneur en potassium dans les volumes de scories anciennes antérieurement enregistrés. Il est difficile de parler du statut sanitaire général des habitants des régions minières ayant en vue qu'un petit nombre de restes squelettiques a été étudié jusqu'à présent et cela sans matériel de Novo Brdo, centre minier médiéval le plus important. L'analyse anthropologique indique les problèmes causés par l'activité physique lourde et par les mauvaises conditions hygiéniques. Les connaissances actuelles sur l'influence des métaux lourds donnent un aperçu des effets des pratiques minières antérieures sur l'environnement et sur la santé des gens. La décomposition de sulfures dans les déchets, l'écoulement d'eau acide de vieilles galeries ainsi que la décomposition des scories médiévales influencent la pollution actuelle des eaux et des sols dans le voisinage des centres miniers Rudnik et Srebrenica. Ce pourraient être certaines raisons pour lesquelles la vie était dangereuse dans cette région pendant la période du XV $\mathrm{V}^{\mathrm{e}}$ au XVII ${ }^{\mathrm{e}}$ siècle. Dans l'avenir, les recherches archéologiques postérieures incluant d'autres disciplines scientifiques vont contribuer à une meilleure compréhension des relations entre les gens et l'environnement dans les régions minières de la Serbie médiévale.

Mots-clés: exploitation minière, fonderies, moyen âge, Serbie, pollution, environnement

Primljeno / Received: 31. 05. 2021.

Prihvaćeno / Accepted for publication: 20. 07. 2021. 